\title{
Thickening rhetorical political analysis with a theory of distance: negotiating the Greek episode of the eurozone crisis
}

\begin{abstract}
Rhetoric has re-emerged in political analysis. We identify two broad trends in the rhetorical analysis of politics, 'thin' and 'thick'. Thin conceptions view rhetoric as primarily a matter of oratory. In contrast, the authors of Rhetorical Political Analysis have developed an emerging thick approach, in which rhetorical concepts are applied more broadly and with more depth. However, this approach is significantly limited in its influence because it does not adequately speak to other sub-disciplines in political science, in which non-rhetorical theories are preferred. This shortcoming is addressed by applying Meyer's new philosophy of rhetoric. The approach supports methodological extension through a theory of practice, grounded in social distance. An analysis of the Greek episode of the eurozone crisis shows how rhetoric is used by key actors for the purpose of strategic positioning, in concert with non-rhetorical means of distanciation, namely economic and political relations.
\end{abstract}




\section{Thickening rhetorical political analysis with a theory of distance: negotiating the Greek episode of the eurozone crisis}

Gareth Price-Thomas, School of History, Politics and International Relations, University of Leicester, University Road, Leicester LE1 7RH. Email: gpt5@leicester.ac.uk

Nick Turnbull, School of Social Sciences, University of Manchester, Oxford Rd, Manchester M13 9PL. Email: nick.turnbull@manchester.ac.uk

Rhetoric has re-emerged in political analysis. In contrast to traditional approaches to rhetoric which understand it primarily as oratory, the new scholarship treats rhetoric not only as an object of research but as the basis of an analytical framework for the study of political language. In particular, in the UK, Finlayson, Martin, and Atkins have developed this new approach Rhetorical Political Analysis (RPA) - to study political language, ideology, and strategy (Finlayson, 2007; Finlayson and Martin, 2008; Atkins and Finlayson, 2013; Atkins et al., 2014; Martin, 2013, 2015; Walter, 2016; see also Toye, 2013). They aim to show the contribution to political science of conceptualising political language as rhetoric, as well as the benefits of using concepts from rhetoric scholarship in the study of political communication. British scholars increasingly draw upon the long history of rhetoric scholarship in the US (for example, Burke, 1969; Crosswhite, 2013) and in continental Europe (Perelman, 1982; Palonen, 2015). This is part of a general renewal of interest in rhetoric in political studies, for example in public policy scholarship (Majone, 1989; Dryzek, 2010; Fischer and Gottweis, 2012; Griggs and Howarth, 2013).

In this article, we identify two broad trends in the rhetorical analysis of politics, 'thin' and 'thick'. Thin approaches understand rhetoric as a mere technique: that is, as a technical discipline concerning the arrangement and delivery of speech, focused upon oratory. Thin approaches are entirely valid. However, the emerging thick RPA approach endeavours to claim a space for rhetoric as central to political analysis, beyond such limited views. The thick approach seeks to 
overturn the conception that rhetoric is trivial decoration and is of little consequence, and show how it is essential in the search for and maintenance of power.

But there are still some limitations to the RPA approach. We argue that a thick theory of rhetoric must be integrated with other forms of social scientific analysis, rather than remaining separate from them. This is necessary because, despite the renewed interest in rhetoric and its extension to a more in-depth analytical framework, in political science most researchers studying political language prefer to use approaches other than rhetorical ones, such as 'political communication', 'discourse analysis' or 'narrative analysis', for two reasons. Firstly, other approaches are understood to treat language and ideas in more depth than is implied by the predominant, thin conception which characterises rhetoric as occupying the surface, technical territory of communication. Secondly, the mainstream analytical frameworks are considered to be more methodologically amenable to social-scientific investigation than RPA because, due to its basis in the humanities' ideographic tradition, it is difficult to integrate with other methodologies. Rhetoric studies would benefit from a different conceptual basis so that it can operate in tandem with other political science sub-disciplines.

The aim of this paper is to argue for a new thick approach to rhetorical political analysis, based in the concept of distance, as advocated by Michel Meyer. This entails a shift in the conception of rhetorical analysis by reconsidering the philosophical and methodological bases of rhetoric theory. Meyer's theory allows us to embed rhetoric within a relational social science, thereby broadening the relevance of rhetorical concepts. Most importantly, we propose that it sets out a methodological pathway to offer a means of compatibility with other sub-disciplines of political science. In so doing, it seeks to challenge the view that rhetoric is an autonomous field of inquiry. We argue that Meyer's theory permits us to integrate the strengths of thin and RPA theories of political rhetoric, while also improving upon them. 
The article's key contribution is to stake out how this particular approach to the theory of rhetoric renders it compatible with other sub-disciplines of political science. It does so in three parts. The first section of the article presents a critical review of recent scholarship on rhetorical political analysis. It proposes that there are currently two broad conceptions, thin and thick. Taken together, these establish the contribution of rhetoric to contemporary political science and point towards the prospect of embedding rhetoric within a broader conception of political communication. We then argue that these approaches have limited utility in reaching this goal because in them rhetoric is conceptualised so as to limit potential integration with other analytical approaches. The second section introduces Meyer's original philosophy of rhetoric, based on questioning and a theory of distance. It then argues that this rhetorical theory of social practice can be operationalised in such a way as to improve our understanding of politics. In the third and final section, a case study of the eurozone crisis, this amended theory is put into practice. The case study demonstrates the utility of the framework in three ways: 1) an analysis of ethos, logos and pathos in the speech of particular rhetorical actors; 2) the dynamic interplay of rhetorical speech acts both within and across political divides; and 3) the distancing mechanisms at work in eurozone institutions. These three components demonstrate the integration of thin and RPA approaches while also bridging the divide between rhetoric studies and a sub-discipline of political science, political economy.

\section{Existing approaches to analysing political rhetoric: thin and thick}

\section{Thin rhetoric: rhetoric as the object of political analysis}

Many approaches to rhetorical analysis have treated rhetoric primarily as an object. That is, they have conceptualised rhetoric as genres of speech or a set of techniques, as the 'art' of speech oriented towards persuasion, frequently in terms of oratory (see, for example, Crines, 2013; Crines and Hayton, 2015), mostly for the purpose of persuading an audience in the process of 
political deliberation (Condor et al., 2013). Furthermore, this often defines rhetoric as a mere accompaniment to a logic of informal argumentation, relating to its effectiveness (Fairclough and Fairclough, 2012). Political speeches by leaders are the most obvious example. The ability to persuade other political actors and the public has always been a crucial skill for leaders in seeking to gain, use, and hold on to power on a day-to-day basis (Tulis, 1987; Grube, 2013), and in parliamentary debate (Reid, 2014). Rhetorical techniques contribute to the persuasive power of ideologies, relevant for both public sphere debates and within party organisations (Dommett, 2014; Atkins, 2015). They aim for persuasion as discourse that makes arguments and defends against criticisms (Finlayson, 2012, p. 758), both before and after decisions have been taken (Atkins, 2011). Since the advent of television, persuasion takes place increasingly with regard to multiple audiences simultaneously, for example at party conferences which are important opportunities for leaders to persuade both the party membership and the viewing public (Atkins and Finlayson, 2013).

But much of this contemporary rhetoric scholarship already moves beyond thin analyses, looking much deeper than the common view of rhetoric as mere technique. There are many dimensions of rhetoric which cannot be encapsulated by the oratorical focus. For example, ceremonial occasions like the inaugural address by the US President have a deeper social purpose, performing a ritual of social reunification under a key institution after the divisiveness of an election campaign. Similarly, in national celebrations, rhetoric is used to praise the people and celebrate their shared identity, or to reframe national identity in particular ways (Byrne, 2014). Nationalism is rhetorical but also often 'banal' (Billig, 1995), an ever-present but unremarked affirmation of community identification and solidarity. 
Recent research develops the idea of rhetoric as an analytical framework, proposing to extend the utility of the concept beyond speech as an object, to apply to political analysis more generally. RPA aims to integrate political rhetoric into the broader research programme of political science 'concerned with the formation, propagation, development and change of ideas in politics' (Atkins and Finlayson, 2013, p. 162). Like the thin approaches, RPA is primarily concerned with persuasion; 'the arguments found in political speech, and especially the proofs actors bring forward in justifying claims and giving reasons for others to share them [original emphasis]' (Atkins and Finlayson, 2013, p. 162). But this approach diverges from the thin conception of rhetoric as an object, revealing how the form and performance of argumentation is intrinsic to its content. Rhetoric is embedded within an analytical framework, which includes cultural and historical patterns of argumentation. For example, Finlayson (2007) characterises interpretive governance narratives as rhetorical because they work to persuade an audience. Rhetoric actively constructs political culture, rather than being simply a tool for the deployment of preconceived narratives, as in the thin approach.

Martin (2013) also puts forward a theory of political rhetoric, similarly based in persuasion, that aims to integrate the pragmatic concerns of rhetoric with the construction of underlying principles and power relations. He conceives of rhetoric as mediating between politics and 'the political', legitimating certain actors and ideas at the ontological level. The act of persuasion is thus 'both a mundane business and a channel of wider power relations; a process of coalition building and an effort to define higher principles' (2013, p. 7). The theoretical originality of this framework draws on the crucial insight that rhetoric is a situated practice of argumentation (2013, p. 9). As such, it must be linked to the context of a specific time and space, and contributes to this context in return through its technical deployment. Rhetoric is a political practice that continuously remakes the world anew, generating both stability and change in 
meaning. This makes it significantly different from discourse analysis, which operates at a higher level of abstraction (2013, p. 11). Rhetoric is the pragmatic mechanism through which discourses can be built and through which both stable and fluid meanings are put into play. Rhetoric is not exclusive of other approaches to discourse but it is irreducible to them.

Insofar as these works move beyond rhetoric as a technique by showing its deeper connection to social power, they have begun to develop RPA as a thick approach. We can see three significant advantages in moving beyond the thin approach to rhetoric as an object, by showing how the performance and content of rhetoric is intrinsic to power relations. Firstly, RPA shows that rhetoric is interconnected with deeper power structures. Secondly, RPA goes further in proposing that the speaker and audience co-construct political space via rhetorical interaction. Theories of language which treat discourse in isolation from its context - as though discourse constituted a fixed, structuring episteme - are insufficient explanations of the rhetorical. Thirdly, from the performative dimension of RPA, it follows that rhetoric is a situated practice interacting with its social and historical context. This dimension has been a feature of the field in 'rhetorical situation theory', which deals with the interaction between rhetoric and context (Bitzer, 1968; for a new theory of rhetorical situation based on Meyer's work, see Turnbull 2016).

Although the RPA approach helps us see the deeper significance of rhetoric, it raises a methodological problem: it does not lend itself well to usage outside of its own field. Rhetoric is clearly a highly interpretive discourse; the speaker has quasi-infinite options and the audience has many degrees of freedom to interpret from its own perspective. The diversity within an audience ensures that meaning cannot be contained. So, given that rhetoric supposes, correctly, that language is polysemous - a difficulty enhanced by the multiplication of audiences in the age of broadcasting and the internet - the analysis of meaning and argumentative strategy becomes highly problematic. For instance, comparative rhetorical analyses are difficult to conduct for 
reasons of instability of context. Instead of trying to come to terms with an extremely wide variety of possible interpretations of rhetoric and the situations of its utterance, researchers can easily prefer to side-line rhetoric and analyse the situation itself in order to understand its underlying structural possibilities, as political sociology does already. To deal with this issue, some authors have gone further towards the humanities, borrowing its conceptual schemas to propose loose commonalities, such as rhetorical genres (for example, Jackson and Linkugel, 1978; Miller, 1984). However, these make no progress towards integrating rhetoric within social scientific analyses concerned with generalisable theories, mostly based in non-interpretive methodologies. Ultimately, whatever the rhetorical alternatives available to individuals, what rhetoric concerns fundamentally is the actual relationship between speaker and audience. Rhetorical techniques are not autonomous from the social relations they mediate. And these relations encompass much more than rhetorical discourse. A social scientific analysis of rhetoric and situation needs a common basis upon which to relate different methodological approaches.

A subsidiary problem to this methodological objection is that RPA, like thin approaches, presumes that persuasion is the defining feature of rhetoric. Because it is not integrated with a broader theory of social relations - in which people interact in many ways other than persuading one another - it is too one-dimensional in the way it characterises communication. In a democracy, it is easy to presume that the right to vote and to free expression is paramount because it lies behind every debate, hence individuals have a choice of how to interpret discourse. It follows from this that the speaker consciously intends to persuade and that the audience is, or is not, persuaded. However, in practice, people do not exercise choices about all questions, but are instead often happy to repress them in favour of the accepted answers (Schutz, 1972: 81). We know that rhetoric can be used equally to shut argumentation down, or to avoid questions altogether. It can respond to problems by glossing over them, articulating them in such a way as to sate the audience, or by leaving answers ambiguous so as to avoid conflict. Rhetoric thus depoliticises as much as it deliberates. Rhetoric-as-persuasion also excludes most 
discourse in authoritarian states, in which rhetoric takes the form of propaganda, not persuasion (O’Shaughnessy, 2004). Rhetoric is a flexible discourse used in both sincere deliberation over problems and the manipulative repression of them. A thick theory of rhetoric should account for all its properties and all its uses.

We have not yet arrived at a truly thick theory of rhetoric. One can be developed upon these insights, but it must go further than previous approaches, which accept too many limitations on rhetoric, either conceptually or methodologically.

\section{The negotiation of distance as a thick theory of rhetoric}

The basis of a thick theory of rhetoric can be found in a new philosophy, put forward by Michel Meyer $(2008,2010)$. He proposes a general definition: 'Rhetoric is the negotiation of distance between individuals in regard to a given question' (2008, p. 21, our translation; see also, Meyer, 2010). The first point of note is that this definition takes us in a different direction from language-based approaches which envision reality as 'discursive'. Instead, it integrates language within a primary, embodied social relation between individual actors, variable according to the distance between them. That distance is constituted partly by discourse, but also by other means, including material and institutional questions. Most importantly, any approach to rhetorical analysis which seeks a wider audience must engage with non-rhetorical modes of political studies. Rhetoric is not ontologically autonomous; it is but one means of negotiating social relations, among others. Therefore, rhetoric can be integrated with other analytical frameworks via the commonality of distance. The second key point to note is that this theory is based in questioning. When two (or more) individuals communicate, it is because they have a question or problem in mind. Rhetoric is necessary because, in politics, there are no necessary answers. We can debate the options, putting forward arguments to persuade one another of the best answer; we can use rhetorical devices to avoid confronting our choices, and allow established answers to prevail; or 
we can use propaganda to assert overarching values and shut down questioning. This definition includes persuasion but also goes beyond it.

Whichever mode of rhetoric is used, what is at stake, implicit beneath the treatment of substantive questions, is the question of the distance between these same individuals who are engaged in discourse. That is, their relative distance is an implicit question which is treated via another, more explicit question, the subject of the dialogue. Rhetoric is an open mode of communication because it concerns the discussion of questions, which are contingent because they have many equally possible answers. And, in turn, these answers respond to the question of the relative social distance between the interlocutors. In each case, what is negotiated are two concurrent questions, the explicit one having its own status but also pertaining to a deeper and often unspoken social question. Thus, rhetoric is one means by which we negotiate social relations, always dynamic and open to question in each new encounter, particularly in politics.

This questioning dimension of the framework has a broad reach because it applies to many modes of rhetoric, including persuasion. It applies to deliberative discourse, in which individuals deploy arguments in order to persuade one another; if they reach agreement, they move closer to one another, and if they disagree, they move further apart, perhaps even to the point of violent conflict. The framework can also be applied to the use of figurative discourse for persuasive ends, such as when speakers use metaphors or tropes to generate distance within language, which requires audiences to search for the meaning and thus has a pleasing effect. It applies to rhetorical manipulation, in which an audience is led towards a particular conclusion, often through the emotions. It applies to ritual performances, in which communities enact their shared social norms and customs and thus their closeness, without any resort to persuasion. It also applies to rhetoric used as an elision, when it glosses over or avoids specific questions in order to circumvent conflict that would otherwise put individuals at a further distance, for example, steering clear of mentioning religion or politics at a dinner party. Alternatively, speakers 
may choose to provoke such questions - knowing full well that each will never persuade the other - in order to deliberately distance themselves from one another. This view even takes into account the fundamental possibility of rhetorical indifference, when a question simply does not interest an interlocutor at all, and the answer is that the parties do not enter into any relationship.

Using rhetoric in this way, as negotiating social distance, means it can work in tandem with other relational analyses, all subsumed within a general theory of social action as the production, negotiation, and modification of social distances. Each individual has the agency to take alternative rhetorical positions in regard to their distance from the other, but is also constrained by social structures pertaining to the situation. Ultimately there are three outcomes in regard to distance. Rhetorical negotiation - no matter whether through overt persuasion or implicit deproblematisation - may either bring individuals closer together (-), maintain their distance $(=)$, or drive them further apart $(+)$. We refer to this as 'distanciation' to indicate these full possibilities, as opposed to the common term 'distantiation' which signifies to put someone at a greater distance (see Turnbull 2014). This grounding in distance strikes a common note with political constructivism (Hay, 2001) and the strategic-relational approach (Jessop, 2008), while also sharing a conceptual basis with relational sociology, which aims to provide an alternative to both individualist and holist perspectives (Simmel, 1955; Bourdieu, 1984; Bottero and Prandy, 2003; Crossley, 2011). Crucially, this methodological basis supports the integration of rhetoric with other frameworks in politics and across the social sciences. It does so by generating a measurement framework that supports an analytical reduction in the myriad possibilities of meaning in specific situations, but without rendering rhetoric secondary in any way, in contrast to the thin conception.

This grounding of rhetoric in social theory is further achieved through the third major element of Meyer's theory, his radical re-imagination of Aristotle's definition of the means of persuasion - ethos (character), logos (reasons) and pathos (emotions) - in performative terms, to 
theorise rhetorical communication in general. Meyer reviews the history of rhetoric and argues that Aristotle, and other subsequent theorists, tended to emphasise one of this triadic set over the others, leading to imbalance (Meyer 2008). Instead, Meyer makes them equivalent and necessary elements of each and every rhetorical exchange. In this theory, a speaker (ethos) treats his/her distance from an interlocutor (pathos) via a question (logos). This is based upon Meyer's philosophy of questioning, such that a speaker (ethos) corresponds to the question of the Self, the audience (pathos) to the question of the Other, and the substantive question (logos) to the question of the World (Meyer 2008). In a dialogue, speakers treat a common question, becoming ethos and pathos in turn, negotiating the distance between themselves through their appeals and emotional reactions. This makes two important theoretical advances: 1) it equalizes Aristotle's three concepts within each and every instance of communication, and 2) it embeds the rhetorical within the performance of social relations, rather than leaving it as a detached, technical property of communication. That is, it locates rhetoric within a theory of social practice. This performative dimension is one of the main elements of RPA. But here, within an embedded perspective on practice, it encompasses character and values, arguments, and emotions altogether in the one whole. The adaptation of Aristotle's categories to the performance of rhetoric improves and enhances upon RPA research that emphasises this dimension of speech acts. The use of rhetoric, even in the technical sense as the art of speech, cannot be disconnected from the reality of social differences. Thus, rhetoric is no longer restricted to the technical, or 'thin' conception, because it is linked with the general property of distanciation in social relations. This relational perspective shows how rhetoric contributes to the ways in which 'actors... are formed and continually re-formed in and through interaction' (Crossley 2011: 15). In other words, this rhetoric is truly 'thick'.

Now, one might object that 'distance' is no better than 'difference' in analysing rhetorical distinctions. Many analyses of political discourse have been based on identifying ontological differences in which a certain type of social actor is cast as radically 'Other' to a presupposed, 
central ontological identity. However, such analyses tell us little about the subtleties of political negotiation nor about the very real, variegated differences between social actors. Rhetoric offers an infinite variety of terminology by which to define and redefine the difference between actors along a continuum of distance. We can already find excellent examples pointing to the importance of distance in social relations. In rhetoric, the idea of distance was hinted at by Kenneth Burke (1969, p. 20), who argued that rhetoric promotes identification via the achievement of common interests through persuasion. Aristotle also speaks of distance, in his characterisation of an audience experiencing fear. In political sociology, social differences between races are described by degrees of distance (Ford, 2008). In cultural sociology, distinctions by levels of social, economic, and cultural capital are also measured on a continuum of distance (Bennett et al., 2009), while in sociolinguistic 'accommodation theory', speakers adjust their accents to reduce the distance from their audience (Gallois et al., 2005). The distance concept has a further methodological advantage in that the problem of a speaker's intention is rendered secondary; what is primary is the relational effect of rhetoric, intended or otherwise. In any political debate, variations in terminology or the delivery of speech may be seized upon as signifying a more proximal or more distal relationship between conflicting parties, with consequent political implications.

One might also object that grounding rhetoric in the concept of distance unnecessarily limits the scope of rhetoric. We reject this view. Firstly, we refer readers to Meyer's larger body of philosophical work - which we have only briefly sketched here (see Meyer, 1994, 1995, 2000) - which grounds rhetoric in a principle of questioning, thereby integrating it as a fundamental element of reasoning, and overturning its previous, longstanding separation from science as found, for example, in both Aristotle and Perelman. Meyer's work is very much a 'deep' theory of rhetoric, and belongs in the company of other similar works which consider its relationship with philosophy (for example, Crosswhite, 2013). Meyer's work also belongs in the tradition of 'big' rhetoric (see Burke, 1969; Gaonkar, 1990; Simons, 1990; Schiappa, 2001) because it aims to 
show how rhetoric is a general property of communication, used in politics, law, and literature, and applicable to visual symbols, rituals, and all symbolic relations. We have no room here to debate the value of Meyer's theory against the major rhetoric theorists. Such debates will take place in other arenas. For now, we argue that, for political research, a big and deep theory of rhetoric such as this is necessary for a truly thick approach.

This thick rhetoric has advantages for rhetorical political analysis. Firstly, it accounts for persuasion but also locates rhetoric as more deeply embedded in social relations. Therefore it supports thin analyses as well as extending rhetorical concepts beyond oratory. Secondly, it incorporates all three of Aristotle's concepts in every rhetorical situation, thereby unifying the analytical framework and showing its general utility. Thirdly, and most importantly, it supports the integration of rhetoric with other modes of political analysis which also utilise the concept of distance. In all these respects, this is an integrated, thick approach to rhetorical analysis. In the following section, we apply the theory to a contemporary case in political economy, the eurozone crisis.

\section{Negotiating the Greek episode of the eurozone crisis}

The following analysis puts this thick theory of rhetoric into action. It integrates the analytical framework above with a particular social scientific approach, political economy. The analysis is therefore cognate with a specific conception of social distance, which in turn informs our conception of the rhetoric deployed.

We present an analysis of one particular stage of the eurozone crisis: the left-wing party SYRIZA's attempts to extract concessions relating to the Greek national debt from the so-called 'Troika' (European Commission, European Central Bank, and International Monetary Fund). Between SYRIZA's initial national election victory in January 2015 and their acceptance of a new and very harsh bailout contract in July of the same year, the Greek government exercised a 
number of rhetorical strategies. They did so in the hope that they might be allowed to implement some of the anti-austerity policies which were integral to the party's ideological constitution and on which they had campaigned in the election: through, for instance, a further partial reduction of the debt, or a slackening in the pace of repayment.

SYRIZA is a sprawling and complex party (Ovenden, 2015) with a large number of significant rhetorical actors. Likewise, the Greek party faced a number of antagonists, not least the Troika. But for the purposes of this brief case study we shall here focus on the statements of four specific figures, two from each camp. Among Greek government representatives, it seems obvious to focus on Prime Minister Alexis Tsipras and finance minister Yanis Varoufakis. Selecting SYRIZA's antagonists is a slightly more complex task, since we could choose from several major politicians affiliated with the Troika. But for illustrative purposes it will work effectively to select Tsipras and Varoufakis's German national counterparts: Christian Democratic Chancellor Angela Merkel and her finance minister Wolfgang Schäuble. Doubtless, they had this international role thrust unwillingly upon them to some extent, but their rhetoric on the Greek situation has been among the most highly-scrutinised and most often-repeated in the media over this period, and ultimately the Christian Democrats proved themselves powerful opponents of SYRIZA's anti-austerity project.

Given that their party occupied the epicentre of the crisis during this six-month timeframe, let us first assess the rhetoric of Tsipras and Varoufakis. From SYRIZA's perspective it was clear from the beginning that, to extract any meaningful concessions from the Troika, the relatively cautious diplomatic approach adopted by preceding governments - centre-left and centre-right - would not suffice. Instead, the party would have to attempt a decisive recalibration of multiple relations of distance.

It could achieve this, most obviously, through rhetorical acts of persuasion. Utilising the RPA framework, we can analyse the rhetoric adopted by SYRIZA in three dimensions. The 
ethos of Tsipras and Varoufakis's messages was partly centred around the ideal of democracy, one which the Troika was allegedly betraying in its refusal to comply with the mandate of an anti-austerity government (Tsipras: 'certain institutional actors [are] displaying a total indifference to the recent democratic choice of the Greek people', Guardian, 2015f; Varoufakis: 'Let the people decide. (Funny how radical this concept sounds!)', Telegraph, 2015b). The logos of SYRIZA's appeal was that Greece was not in a position to repay its debts according to existing timetables (Varoufakis: 'We are not prepared to carry on pretending and extending, trying to enforce an unenforceable programme', BBC News, 2015; Tsipras: 'The debt must become viable', Guardian, 2015b), at least not without contributing to the escalation of what Tsipras has called 'the humanitarian crisis' (Guardian, 2015d). More broadly and in more abstract terms this logos was derived from Keynesian economic theory (Varoufakis himself being an admirer of Keynes; see Varoufakis, 2016), which emphasises sustainable debt reduction through stimulusdriven growth rather than through austerity (Tsipras: 'We need time to breathe and create our own medium-term recovery programme', Telegraph, 2015a), and SYRIZA's own pre-existing leftof-centre ideological coordinates. Finally, the Greek government sought to exercise pathos through more emotional demands for some relief for the downtrodden. For instance, Tsipras spoke about the 'humiliation and suffering' (cited in Bistis, 2016: 43) and wounded 'dignity' (New York Times, 2015c) of the Greek people.

However, our own analytical framework allows us to go beyond rhetoric-as-persuasion to see the other side of the Greek strategy, which was one of repositioning, the management of distance. This repositioning entailed, first, an increase $(+)$ in the distance between the Greek government and the Troika and its most prominent allies. On announcing SYRIZA's election victory, Tsipras struck a tone which hinted at the great struggle to come ('Greece is leaving behind the destructive austerity, fear and authoritarianism', Independent, 2015a); and his first act in office - a clear symbol of defiance to Merkel's government - paid homage to Greek activists killed by occupying Nazi forces during the Second World War (Guardian, 2015a). Throughout the 
period, Varoufakis was to take a relatively strident tone, refusing to negotiate with the Troika, emphasising the alleged non-negotiability of several key demands ('The lines that we have presented as red will not be crossed', New York. Times, 2015b) and at one point describing a set of deadlines the government was supposed to meet as 'inhuman' (Observer, 2015). And in a display of visual rhetoric, both men consistently refused to wear a tie in meetings with foreign counterparts (New York Times, 2015a), projecting an outsider ethos. There is a certain element of persuasion in all such instances, but they cannot be reduced to this - especially regarding the references to National Socialist crimes, which were inevitably going to be received as an insult (pathos) to the Merkel government, thus serving to antagonise more than anything else and possibly encouraging the Germans to harden their stance. The intention was predicated upon an acceptance of the pre-existing distance between the Greek and German camps, and was intended to drive an even clearer wedge - to achieve a new distanciation $(+)-$ between SYRIZA and the Troika.

Simultaneously this latter part of the strategy - as well as the former, more obviously persuasive element - was targeted at other possible allies. Tsipras and Varoufakis (ethos) hoped to rally some of the more Keynesian governments of Europe (pathos) to their cause (-) (Chatzistavrou, 2016: 39). The French and Italian governments - for instance - were already at some ideological distance from Merkel's ordoliberal line, and some way closer to SYRIZA than were the Christian Democrats. Furthermore, in terms of political economy, geopolitics and geography, their states occupy a position some way out from the core of European fiscal stability represented by the EU institutions and by Germany; in the event of worsening economic circumstances, they might themselves one day face a comparable dilemma to Greece. So if SYRIZA could decisively pull any such governments towards its position (-), this would place pressure on Merkel and the Troika to reduce their own distance from France, Italy and so on, through taking steps in their direction. This would be more possible still if Germany's line hardened in response to fire from SYRIZA. 
What, then, of the Christian Democrats' response? What kind of an ethos did they present, and by what pathos did they react to the Greek provocations? In contrast to SYRIZA's gambit, the task of Merkel and Schäuble was to maintain the existing distanciations (=) between eurozone actors; that is, to largely preserve relations as they were, thereby gradually forcing the Greek government closer towards their own position (-). Two contrasting reactions (pathos) were evident. Firstly, the finance minister issued the strongest criticisms of his negotiating partners, who had been, Schäuble claimed, 'destroying hope in an incredible way' $(+)($ Guardian, 2015i). But the Chancellor, secondly, adopted a more diplomatic tone (-) (Merkel: 'I always approach these things with the attitude, if there is a will there is a way', Guardian, 2015g). Thus, by paying attention to the interrelation of individual rhetorical acts, we can see that these two actors adopted a two-pronged strategy of distanciation (+/-). The more conciliatory rhetoric of the more powerful actor softened the face of that power, and thereby mollified - either subsequently or in advance - the harsher words of her finance minister. This produced a moderation in the overall distancing effect. It allowed the Germans to strike some kind of overall balance $(=)$, voicing trenchant critique alongside a degree of support. The latter is beneficial for diplomatic relations, even when it is recognised as potentially insincere - another rhetorical act going beyond mere persuasion.

The rhetoric deployed by the German government cannot be understood in abstraction from other rhetorical acts; it was calculated to counteract the Greek statements. The ethos it projected was centred on an equal treatment of all eurozone member states, and more broadly and implicitly a re-legitimation of the existing rules of the EU (Merkel: 'Nothing different is being done to Greece', Die Welt, 2015). This incorporated a direct response to the Greek arguments on democracy, as Schäuble indicated that the German government also had to attend to its own voters' wishes (Guardian, 2015c). In this way the Germans presented themselves as essentially moderate in their demands, in contrast to SYRIZA's depiction of them. In terms of logos the argument was based on the liberal and internationally dominant assumption that, while 
a difficult process, austerity can work as a sustainable method of debt reduction - and indeed, that it was beginning to work until SYRIZA's election derailed the process (Schäuble: 'We're in a much harder situation than before. It was always difficult. But it has just kept getting more and more difficult since January', Guardian, 2015h). The predominant form of pathos in Christian Democratic rhetoric, deployed towards its potential allies, sought to generate in European partners was surely fear; fear that Tsipras's demands could cause irreparable damage to the eurozone and the European project (Merkel: 'Europe's credibility naturally depends on us respecting rules and being reliable with each other', Reuters, 2015a), that - and this part was aimed primarily at the Greeks themselves - the Prime Minister's intransigence might bring about a Greek exit ('Grexit' +) from the monetary union (Schäuble: 'because we don't exactly know what those responsible in Greece will do, we cannot rule it out'; Independent, 2015b).

It is worth noting that this approach required a good deal of sensitivity. The Christian Democrats had to speak to several audiences. In other words they as ethos were seeking out multiple forms of pathos, often - usually through the media - at the same time. Moreover, the desires of these audiences were to some extent mutually exclusive, meaning that the Germans could not seek to fully persuade any of them. So, they also had to attempt to manage the distances between each - to maintain a certain positioning of all relevant actors $(=)$ - as best they could. On the one hand, Merkel and Schäuble needed to keep their electorate in mind, an electorate which had come to resent any further financial contributions to Greece (Oppermann, 2012: 511), particularly when German public spending had itself been placed under severe budgetary constraints in recent years (Bulmer, 2014: 1256-1257). Any significant increase in distance $(+)$ between Merkel and her voting public on this point could have cost her party at the polls. On the other hand, on the international level the Christian Democrats were under significant pressure in the opposite direction. Germany was called upon to play a leading role in the negotiations. But it could not be seen to contribute to the risk of Grexit, lack sensitivity in its engagement with SYRIZA's demands, nor straightforwardly overrule the somewhat more 
Keynesian member states. Relating to these points, note Italian Prime Minister Renzi's exasperated 'enough is enough' (Reuters, 2015b) and the Luxembourg foreign minister's ominous reference to 'Germany's reputation in the EU and the world' (Telegraph, 2015c). This was partly a question of immediate strategy - the need to prevent France, Italy and others from moving closer to SYRIZA's position - and a longer-term issue relating to post-war Germany's reluctance to imply any hegemonic aspirations in international affairs. The latter aspect can also be interpreted through a lens of relative distance, this one geopolitical in nature.

However, without discounting the impact of Merkel and Schäuble's rhetorical strategy, including its persuasive elements, extra-rhetorical forms of distance favoured Christian Democratic success more than they hindered it. A brief social scientific examination of two of these forms, drawing on further insights from the discipline of political economy, helps us come closer to explaining SYRIZA's defeat in July. First, in terms of institutional politics, the Christian Democrats had behind them not just the ethos but the full material weight of the existing accords, rules and mechanisms of the eurozone and EU, to which they were - as founder member and largest national population - relatively proximal (see the discussion on German influence at the European level in Clift and Ryner, 2014). This power bestowed by the existing procedures was indicated in a statement by Schäuble around the beginning of the earliest negotiations with SYRIZA - 'We have a programme [...] The programme is either brought properly to an end or there is no programme' (Guardian, 2015e) - and a similar sentiment can be found in Schäuble's claim before SYRIZA's election that '[a]ny new government must stick to the contractual agreements of its predecessors' (BBC News, 2014). Upon its election and arrival at the European level, SYRIZA stepped onto an institutional pitch structured by the EU in which its demands were intrinsically far-fetched. Redrawing the lines on the playing field was always going to be more difficult than simply reproducing them. 
The second extra-rhetorical form of distance is economic in nature, and concerns - to take up an already-spatial metaphor from world-systems theory - the core-periphery relations implicit within the eurozone. The Greek economy is small in comparison with those which make up the centre of European economic activity, Germany in particular (quite aside from their opposing roles as debtor and creditor). We should not forget that 'it was Germany (or the Bundesbank) who wrote the rules for the new currency' (Stockhammer and Köhler, 2015: 39), and today, still, Greeks stand at some distance from the point at which EU-wide decisions on economic governance are made. We can go further than this, though. Germany's own economic power today is actually partly reliant upon the very weakness of Greece and of other peripheral states. As a relatively successful export-driven economy, it benefits from the undervaluation of the German currency granted to it by eurozone membership and by the very problems currently besetting the European South. And as a country which consistently reports - and relies upon - a trade surplus, it needs other states (whether in the eurozone or beyond) to run trade deficits. Despite the commonly-held assumption that Germany is a fiscal model worthy of emulation, the German growth strategy simply could not work for the majority of states; it is 'definitionally impossible' (Thompson, 2013: 730). Furthermore, the very strategy pushed by the EU to improve competitiveness through cutting or moderating wages means that catching up with Germany would entail a fall in living standards and rise in unemployment so protracted as to be barely feasible for a democratic country (Flassbeck and Lapavitsas, 2015: 141-2). The Christian Democrats do not acknowledge these points in their rhetoric, but it remains the case that the relations of economic distance between Germany and Greece are dialectical, and structured by the euro in such a way as to maintain the latter's weaker position.

All of the above presupposes a particular interpretation of the various forms of social distance underlying the events under study. Our analysis draws on post-Keynesian and critical approaches and as such has more in common with social democratic analyses of the situation than with the more liberal perspective offered by Merkel and Schäuble. This integration across 
disciplines has allowed us to render rhetoric more amenable to analysis, while adding greater depth. However, any social scientific approach with a clear theorisation of social relations, one which goes beyond the rhetorical, can be drawn upon and made compatible with this unifying framework. While this case study was selected because it can concisely illustrate the approach's various facets, it has a wide potential scope of application within the social sciences. As we have shown, rhetoric has a key role in negotiating distances, particularly by exaggerating them or reducing them as part of political negotiations. But distance, as its underpinning construct, supports an analysis which can synthesise rhetoric with other major social scientific modes of analysis.

\section{Conclusion}

This article set out to consider the contribution of rhetoric to political analysis. It categorised current conceptions of rhetoric into two camps, thin and thick, the latter best found in RPA. However, it concluded that these views are limited. We introduced a new philosophy of rhetoric and demonstrated that a truly thick theory of rhetorical analysis can be pursued through Meyer's conception, based in questioning and distance. This thick theory provides an entirely new perspective, incorporating but moving well beyond thin theories that study rhetorical techniques, and beyond recent RPA theories. Our application of Meyer's theory of rhetoric shows how the subject can be embedded within a theory of social relations, based upon distance, and allows rhetorical concepts to be applied at a deeper level than before. The utility of the approach is in moving beyond thinking of rhetoric as an autonomous ontological category, to integrate it with other social scientific disciplines.

This is not necessarily opposed to other theories of rhetoric, but it is unique in seeking to build bridges with other political science sub-disciplines by providing a theoretical and methodological basis which overlaps with these other approaches. Distance is this common 
basis. By defining rhetoric within a relational conception of society in which distance is the primary question, we can use rhetoric to compliment the analysis of the central questions of political studies. A framework based in questioning and distance does not dispense with wellknown modes of analysing rhetoric, but it does provide a parsimonious and eloquent definition which supports a deeper and more comprehensive engagement with political rhetoric and the rhetorical in political studies. 


\section{References}

Atkins, J. (2011) Justifying New Labour Policy. Basingstoke: Palgrave Macmillan.

Atkins, J. (2015) 'Narrating One Nation: The Ideology and Rhetoric of the Miliband Labour Party', Politics 35 (1), 19-31.

Atkins, J. and Finlayson, A. (2013) “... A 40-Year-Old Black Man Made the Point to me”: Everday knowledge and the performance of leadership in contemporary British Politics', Political Studies 61 (1), 161-77.

Atkins, J., Finlayson, A., Martin, J. and Turnbull, N. (eds.) (2014) Rhetoric in British Politics and Society. Basingstoke: Palgrave Macmillan.

BBC News (2014) 'Greece crisis: Schaeuble warns over reform', 30 December. Available at: http://www.bbc.co.uk/news/world-europe-30629269 (accessed 20 October 2016).

BBC News (2015) 'Greece economy: Merkel rules out more debt relief, 31 January. Available at: http://www.bbc.co.uk/news/world-europe-31072321 (accessed 4 November 2016).

Bennett, T., Savage, M., Silva, E., Warde, A., Gayo-Cal, M.G. and Wright, D. (2009) Culture, Class, Distinction. London: Routledge.

Billig, M. (1995) Banal Nationalism. London: Sage.

Bistis, G. (2016) 'From Karamanlis to Tsipras: The Greek Debt Crisis through Historical and Political Perspectives', Mediterranean Quarterly 27 (1), 30-54.

Bitzer, L. (1968) 'The Rhetorical Situation', Philosophy \& Rhetoric 1 (1), 1-14.

Bottero, W. and Prandy, K. (2003) 'Social Interaction Distance and Stratification', British Journal of Sociology 54 (2), 177-97. 
Bourdieu, P. (1984) Distinction: A Social Critique of the Judgement of Taste. London: Routledge \& Kegan Paul.

Bulmer, S. (2014) 'Germany and the Eurozone Crisis: Between Hegemony and Domestic Politics', West European Politics 37 (6), 1244-1263.

Burke, K. (1969) A Rhetoric of Motives. Berkeley and Los Angeles: University of California Press.

Byrne, B. (2014) 'Rhetoric and Multiculturalism: David Cameron's "King James" speech and the crisis of multiculturalism', in J. Atkins, A. Finlayson, J. Martin and N. Turnbull (eds.) Rhetoric in British Politics \& Society. Basingstoke: Palgrave Macmillan, pp. 119-32.

Chatzistavrou, F. (2016) 'The politics of SYRIZA in Europe: From left-wing radicalism to postleft managerialism', CIDOB (Barcelona Centre for International Affairs). Available at: http://www.cidob.org/en/articulos/monografias/grecia/the_politics_of_syriza_in_euro pe_from_left_wing_radicalism_to_post_left_managerialism (accessed 28 August 2016).

Clift, B. and Ryner, M. (2014) 'Joined at the hip, but pulling apart? Franco-German relations, the Eurozone crisis and the politics of austerity', French Politics 12 (2), 136-163.

Condor, S., Tileaga, C. and Billig, M. (2013) 'Political Rhetoric', in A. Huddy, D.O. Sears and J.S. Levy (eds.) Oxford Handbook of Political Psychology. Oxford: Oxford University Press, pp. 262-98.

Crines, A.S. (2013) 'An Analysis of George Galloway's Oratorical and Rhetorical Impact', Politics $33(2), 81-90$.

Crines, A.S. and Hayton, R. (eds.) (2015) Conservative Orators from Baldwin to Cameron. Manchester: Manchester University Press.

Crossley, N. (2011) Towards Relational Sociology. London: Routledge.

Crosswhite, J. (2013) Deep Rhetoric: Philosophy, Reason, Violence, Justice, Wisdom. Chicago: University of Chicago Press. 
Dommett, K. (2014) 'Ideological Quietism? Ideology and Party Politics in Britain', Political Studies. Epub ahead of print 24 September DOI: 10.1111/467-9248.12160.

Dryzek, J.S. (2010) 'Rhetoric in Democracy: A systemic appreciation; Political Theory 38 (3), 319_ 39.

Fairclough, I. and Fairclough, N. (2012) Political Discourse Analysis: A method for advanced students. London and New York: Routledge.

Finlayson, A. (2007) 'From Beliefs to Arguments: Interpretive Methodology and Rhetorical Political Analysis', British Journal of Politics \& International Relations 9 (4), 545-63.

Finlayson, A. (2012) 'Rhetoric and the Political Theory of Ideologies', Political Studies 60 (4), 75167.

Finlayson, A. and Martin, J. (2008) “'It Ain't What You Say...”: British Political Studies and the Analysis of Speech and Rhetoric', British Politics 3 (4), 445-64.

Fischer, F. and Gottweis, H. (2012) The Argumentative Turn Revisited: Public Policy as Communicative Practice. Durham: Duke University Press.

Flassbeck, H. and Lapavitsas, C. (2015) 'Confronting the failure of the European Monetary Union', in J. Jäger and E. Springler (eds.) Asymmetric Crisis in Europe and Possible Futures. Abingdon: Routledge, pp.131-147.

Ford, R. (2008) 'Is Racial Prejudice Declining in Britain?' British Journal of Sociology 59 (4), 609-36.

Gallois, C., Ogay, T. and Giles, H. (2005) 'Communication Accommodation Theory: A look back and a look ahead', in W. Gudykunst (ed) Theorizing About Intercultural Communication. Thousand Oaks CA: Sage, pp. 121-48.

Gaonkar, D.P. (1990) 'Rhetoric and Its Double: Reflections on the Rhetorical Turn in the Human Science', in H.W. Simons (ed.) The Rhetorical Turn: Invention and Persuasion in the Conduct of Inquiry. Chicago: University of Chicago Press, pp. 341-66. 
Griggs, S. and Howarth, D. (2013) The Politics of Airport Expansion in the United Kingdom: Hegemony, policy and the rhetoric of 'sustainable aviation'. Manchester: Manchester University Press.

Grube, D. (2013) Prime Ministers and Rhetorical Governance. Basingstoke: Palgrave Macmillan.

The Guardian (2015a) 'Alexis Tsipras pays homage to Greek communists at site of Nazi atrocity', 26 January. Available at: https://www.theguardian.com/world/2015/jan/26/alexistsipras-greece-syriza-kaisariani-nazi-german (accessed 4 November 2016).

The Guardian (2015b) 'Greek minister flies to Germany for showdown over debt repayments', 4 February. Available at: https://www.theguardian.com/world/2015/feb/04/greeceshowdown-germany-syriza-debt-crisis-eurozone (accessed 4 November 2016).

The Guardian (2015c) 'Greek and German finance ministers clash at debt relief talks', 5 February. Available at: https://www.theguardian.com/business/2015/feb/05/greek-germanfinance-ministers-clash-debt-relief-talks (accessed 28 August 2016).

The Guardian (2015d) 'Tsipras favours Greek jobless over creditors in defiant policy speech', 8 February. Available at: https://www.theguardian.com/world/2015/feb/08/greeceprime-minister-alexis-tsipras-unveil-anti-austerity-plan-parliament (accessed 4 November 2016).

The Guardian (2015e) 'Greece warned to expect no favours as bailout negotiations begin', 11 February. Available at: https://www.theguardian.com/world/2015/feb/11/greecewarned-no-favours-bailout-negotiations-begin (accessed 20 October 2016).

The Guardian (2015f) 'Alexis Tsipras lambasts “absurd proposals” for Greece debt-deal failure', 31 May. Available at: https://www.theguardian.com/business/2015/may/31/greecealexis-tsipras-lambasts-absurd-proposals-creditors-for-debt-deal-failure (accessed 4 November 2016). 
The Guardian (2015g) 'Greece bailout talks: markets surge on rumours of German compromise', 10 June. Available at: https://www.theguardian.com/business/2015/jun/10/greecebailout-talks-markets-surge-on-rumours-of-german-compromise (accessed 4 November 2016).

The Guardian (2015h) 'Greece crisis: Berlin accuses Tsipras of seeking scapegoats outside own ranks', 1 July. Available at: https://www.theguardian.com/business/2015/jul/01/greececrisis-berlin-blasts-tsipras-scapegoats-germany (accessed 4 November 2016).

The Guardian (2015i) 'Trouble brews on EU doorstep over German plan to shut out Greece', 12 July. Available at: https://www.theguardian.com/business/2015/jul/12/troublebrewing-german-plan-grexit-doorstep-rift-france-greece-eu-euro (accessed 4 November 2016).

Hay, C. (2001) Political Analysis: A Critical Introduction. Basingstoke and New York: Palgrave.

The Independent (2015a) 'Alexis Tsipras is far from Greek orthodox: The Communist "Harry Potter" who could implode the Eurozone', 21 January. Available at: http://www.independent.co.uk/news/people/alexis-tsipras-of-syriza-is-far-from-greekorthodox-the-communist-harry-potter-who-could-implode-the-9992788.html (accessed 4 November 2016).

The Independent (2015b) 'Greek bailout: Schäuble breaks ranks over chance of “Grexit”, 13 March. Available at: http://www.independent.co.uk/news/world/europe/greek-bailoutsch-uble-breaks-ranks-over-chance-of-grexit-10107435.html (accessed 28 August 2016).

Jackson, H. and Linkugel, W.A. (1978) 'On Rhetorical Genre: An Organizing Perspective', Philosopby \& Rhetoric 11 (4), 262-81.

Jessop, B. (2008) State Power: A Strategic-Relational Approach. Cambridge: Polity Press. 
Majone, G. (1989) Evidence, Argument and Persuasion in the Policy Process. New Haven CT and London: Yale University Press.

Martin, J. (2013) Politics \& Rhetoric: A critical introduction. Abingdon: Routledge.

Martin, J. (2015) 'Situating Speech: A rhetorical approach to political strategy', Political Studies 63 (1), 25-42.

Meyer, M. (1994) Rhetoric, Language and Reason. University Park PA: Pennsylvania State University Press.

Meyer, M. (1995). Of Problematology: Philosophy, science, and language, trans. Jamison D with Hart A. Chicago, IL: University of Chicago Press.

Meyer, M. (2000) Philosophy and the Passions: Toward a History of Human Nature. University Park PA: Pennsylvania State University Press.

Meyer, M. (2008) Principia Rhetorica: une theorie generale de l'argumentation. Paris: Fayard.

Meyer, M. (2010) 'The Brussels School of Rhetoric: From the New Rhetoric to Problematology', Philosophy and Rhetoric 43 (4), 403-29.

Miller, C.R. (1984) 'Genre as Social Action', Quarterly Journal of Speech 70, 151-67.

New York Times (2015a) 'On Tour, Greek Leaders Wear No Ties and Aim for Looser Belts’, 3 February. Available at: http://www.nytimes.com/2015/02/04/world/on-tour-greekleaders-wear-no-ties-and-aim-for-looser-belts.html (accessed 4 November 2016).

New York Times (2015b) 'Yanis Varoufakis: No Time for Games in Europe', 16 February. Available at: http://www.nytimes.com/2015/02/17/opinion/yanis-varoufakis-no-timefor-games-in-europe.html?_r=0 (accessed 4 November 2016). 
New York Times (2015c) 'Warnings Raised of a Greek Exit From the Euro', 18 March. Available at: http://www.nytimes.com/2015/03/19/business/international/warnings-raised-of-agreek-exit-from-the-euro.html (accessed 28 August 2016).

The Observer (2015) 'Syriza's honeymoon over as Greece strikes debt deal with EU', 21 February. Available at: https://www.theguardian.com/world/2015/feb/21/syriza-greece-debtdeal-eu-alexis-tsipras (accessed 4 November 2016).

Oppermann, K. (2012) 'National Role Conceptions, Domestic Constraints and the New "Normalcy" in German Foreign Policy: the Eurozone Crisis, Libya and Beyond', German Politics 21 (4), 502-519.

O'Shaughnessy, N.J. (2004) Politics and Propaganda: Weapons of mass seduction. Manchester: Manchester University Press.

Ovenden, K. (2015) Syriza: Inside the Labyrinth. London: Pluto Press.

Palonen, K. (2015) Politics and Conceptual Histories: Rhetorical and temporal perspectives. London: Nomos/Bloomsbury.

Perelman, C. (1982) The Realm of Rhetoric, trans Kluback W. Notre Dame IN: University of Notre Dame Press.

Reid, C. (2014) 'Rhetoric and Parliamentary Leadership: Prime Minister's Questions', in J. Atkins, A. Finlayson, J. Martin and N. Turnbull (eds), Rhetoric in British Politics and Society. Basingstoke: Palgrave Macmillan, pp. 45-57.

Reuters (2015a) 'Merkel, on Greece, says Europe always aims for compromise', 12 February. Available at: http://www.reuters.com/article/us-eurozone-greece-merkelidUSKBNOLG1SF20150212 (accessed 28 August 2016). 
Reuters (2015b) 'Italy’s Renzi to tell Germany to accept Greece deal: newspaper', 12 July.

Available at: http://www.reuters.com/article/us-eurozone-greece-renziidUSKCN0PM08320150712 (accessed August 28 2016).

Schiappa, E. (2001) 'Second Thoughts on the Critique of Big Rhetoric', Philosophy \& Rhetoric 34 (3), 260-274.

Schutz, A. (1972) The Phenomenology of the Social World, Heinemann Educational, London.

Simons, H.W. (ed.) (1990) The Rhetorical Turn, Chicago: University of Chicago Press.

Simmel, G. (1955) Conflict and the Web of Group Affiliations. New York: Free Press.

Stockhammer, E. and Köhler, K. (2015) 'Linking a post-Keynesian approach to critical political economy: Debt-driven growth, export-driven growth and the crisis in Europe', in J. Jäger and E. Springler (eds) Asymmetric Crisis in Europe and Possible Futures. Abingdon: Routledge, pp. 34-49.

The Telegraph (2015a) 'Barack Obama signals support for Greece's call to loosen austerity programme', 2 February. Available at: http://www.telegraph.co.uk/news/worldnews/barackobama/11383848/BarackObama-signals-support-for-Greeces-call-to-loosen-austerity-programme.html (accessed 4 November 2016).

The Telegraph (2015b) 'Greeks announce shock referendum on euro future throwing banking system into turmoil', 27 June. Available at: http://www.telegraph.co.uk/finance/economics/11702829/Greece-to-holdreferendum-on-bailout-deal-with-Europe.html (accessed 4 November 2016).

The Telegraph (2015c) 'The countries that wanted Greece out of the eurozone', 13 July. Available at: http://www.telegraph.co.uk/finance/economics/11734681/The-countries-happy-tosee-Greece-leave-the-eurozone.html (accessed 28 August 2016). 
Thompson, H. (2013) 'Austerity as ideology: The bait and switch of the banking crisis', Comparative European Politics 11 (6), 729-736.

Toye, R. (2013) The Roar of the Lion: The untold story of Churchill's World War II Speeches. Oxford: Oxford University Press.

Tulis, J. (1987) The Rhetorical Presidency. Princeton NJ: Princeton University Press.

Turnbull, N. (2014) Michel Meyer's Problematology: Questioning and society. London and New York: Bloomsbury Academic.

Turnbull, N. (2016) 'Political rhetoric and its relationship to context: a new theory of the rhetorical situation, the rhetorical and the political', Critical Discourse Studies 14 (2), 115131.

Varoufakis, Y. (2016) And the Weak Suffer What They Must? Europe, Austerity and the Threat to Global Stability. London: The Bodley Head.

Walter, R. (2016) 'Rhetoric or Deliberation? The case for rhetorical political analysis', Political Studies. Epub ahead of print 21 April 2016 DOI: 10.1177/0032321716651898.

Die Welt (2015) ,Der nächste Ärger mit Tsipras ist programmiert', 20 March. Available at: http://www.welt.de/politik/ausland/article138637165/Der-naechste-Aerger-mitTsipras-ist-programmiert.html (accessed 28 August 2016). 